\title{
Application of integrated fuzzy VIKOR \& AHP methodology to contractor ranking
}

\author{
Mohamad Rahim Ramezaniyan ${ }^{a}$, Masoud Kazemi ${ }^{b}$, Hadi Jafari ${ }^{* *}$ and Seyyed Majid Elahi ${ }^{\text {b }}$
}

${ }^{a}$ Department of Management, Guilan University, Guilan, Iran

${ }^{b}$ Department of Management, Imam Khomeini International University (IKIU), Qazvin, Iran

\begin{tabular}{|c|c|}
\hline A R T I C L E I N F O & A B S T R A C T \\
\hline $\begin{array}{l}\text { Article history: } \\
\text { Received March 26, } 2012 \\
\text { Received in Revised form } \\
\text { May, 2, } 2012 \\
\text { Accepted } 11 \text { May } 2012 \\
\text { Available online } \\
\text { May } 142012 \\
\text { Keywords: } \\
\text { Fuzzy AHP }\end{array}$ & $\begin{array}{l}\text { Contractor selection is a critical activity, which plays an important role in the overall success of } \\
\text { any construction project. The implementation of fuzzy multiple criteria decision attribute } \\
\text { (MCDA) in selecting contractors has the advantage of rendering subjective and implicit } \\
\text { decision making more objective and transparent. An additional merit of fuzzy MCDA is the } \\
\text { ability to accommodate quantitative and qualitative information. In this paper, an integrated } \\
\text { VIKOR-AHP methodology is proposed to make a selection among the alternative contractors } \\
\text { in one of Iranian construction industry projects. In the proposed methodology, the weights of } \\
\text { the selection criteria are determined by fuzzy pairwise comparison matrices of AHP. }\end{array}$ \\
\hline
\end{tabular}

Fuzzy VIKOR

Contractor selection

\section{Introduction}

Contractors play important role in building projects, which is why contractor selection constitutes a critical decision for project owners. The selection and use of an unsuitable procurement approach could eventually lead to project failure (Luu et al. 2003).

The most important element in construction procurement is contractor selection, particularly, hiring contractors who are performers (Kashiwhgi \& Byfield, 2002). The overall objective of contractor selection process is to reduce project risk, maximize overall value for the project owners, and build close and long-term relationships between members of the project. During the prequalification process, the contractors rank order is prepared according to factors such as experience, financial standing etc. Then, a limited number of the best contractors are invited to tender. Their tenders are then evaluated on the basis of economic criteria and, in some projects, technical criteria (Alarcón \& Mourgues, 2002). 
Today's steadily growing numbers of contractor selection methodologies is the results of the awareness of the construction industry for increasing its procurement process and performance (Wong et al., 2003). There have been tremendous models developed for contractor selection decisions, which are based on the idea of decision-making process (Demirtas \& Stun, 2008). Among those well-known methods, MCDM is relatively new for selection of contractors (Cheng \& Li, 2004).

The VIKOR method is an MCDM method for solving a discrete multicritea problem while there are conflicting criteria (Opricovic, 1998). The primary focuses of such techniques is on ranking and selecting from a set of alternatives, and determine compromise solutions for a problem with conflicting criteria, which can help the decision makers to reach a final decision. The compromise solution is a feasible solution, which makes a solution as close as possible to ideal objectives (Opricovic \& Tzeng, 2004). VIKOR is based on old ideas of compromise programming (Duckstein \& Opricovic, 1980; Yu, 1973). Opricovic (2007) is believed to the first person who introduced an extension of VIKOR to determine fuzzy compromise solution for MCDM problems.

The fuzzy VIKOR method is developed as a fuzzy MCDM method to solve a discrete fuzzy MCDM problem with conflicting criteria and it is presented in Section 2. The background for this method, including aggregation, normalization, DM's preference assessment, and operations on fuzzy numbers are discussed, as a study of rationality that in some way justifies the fuzzy VIKOR method and shows the position of its background in the literature on MCDM. This new method presents a contribution to the practice of MCDM.

In this study, a modified fuzzy VIKOR technique is proposed to make an MCDM selection among alternative contractors. In the proposed methodology, a fuzzy analytical hierarchy process (AHP) determines the decision makers' opinions on the relative importance of the selection criteria. In order to demonstrate the potential of this methodology, an application contractor selection in one of Iranian construction industry projects will be presented.

The rest of the paper is organized as follows: In Section 2, a literature review about Methodologies and Criteria considered used is briefly given. In the third section, Current situation in Ira, In section 4, a modified fuzzy VIKOR methodology is presented. In Section 5, following the determination of the selection criteria and alternatives, the proposed methodology is applied to a selection contractor problem. Finally, in the last section, concluding remarks are given.

\section{Literature review}

\subsection{Used methodologies}

During the past few decades, there have been different techniques proposed for contractor selection, however, many decisions end of accepting low pricing offers. For example, in Denmark a contractor used to be selected by rejecting the two highest and two lowest applicants and choosing the one, which suggests the price closest to the average (Hatush \& Skitmore, 1998; Kadefors et al. 2007; Zavadaskas \& Vilutiene, 2006). In other countries such as Italy, Portugal and South Korea, only the highest and the lowest applicants are discarded and the one, which is close average is chosen. In France, all applicants, which offer abnormally low prices are rejected (Hatush \& Skitmore, 1998; Zavadaskas \& Vilutiene, 2006). In Australia, contractor selection depends on various criteria and the process is used based on two stages: first, the contractor's experience is assessed and then bargaining for low price happens (Kashiwhgi \& Byfield, 2002).

In Saudi Arabia, the lowest bidder is chosen, which is not less than $70 \%$ of the owner's cost estimate (Hatush \& Skitmore, 1998). In Turkey, a two-stage procedure is implemented, however, the lowest price says the last word (Topcu, 2004; Wong et al., 2003; Zavadaskas \& Vilutiene, 2006). In Canada and the USA, particularly in the public sector, the "lowest bidder" is the method of contractor selection, but a bid bond in an amount equal to $10 \%$ of the bid price also needs to be provided 
(Hatush \& Skitmore, 1998; Zavadaskas \& Vilutiene, 2006). In Lithuania, the "lowest bidder" is selected as in Canada and the USA.

Over the past few decades, there have been growing interests in finding appropriate contractors (Nicholas \& Holt, 2003). Competitive bidding is one of the most popular methods in selecting appropriate contractors (Hatush \& Skitmore, 1998). There are literally tremendous attempts into detecting other important factors, which leads to use MCDM techniques (Cheng \& Li, 2004), bespoke approaches (BA), multi-attribute analysis (MAA) (Kashiwhgi \& Byfield, 2002; Topcu, 2004; Cheng $\& \mathrm{Li}, 2004$ ), data envelopment analysis (DEA) (McCabe et al., 2005), multi-attribute utility theory (MAUT) (Wong et al. 2003; Hatush and Skitmore, 1998, Cheng and Li, 2004 ), multiple regression (MR) (Hatush \& Skitmore, 1998, Cheng \& Li, 2004), cluster analysis (CA) (Hatush \& Skitmore, 1998, Cheng \& Li, 2004) fuzzy set theory (FST) (Nicholas \& Holt, 2003; Holt, 1998; Cheng \& Li, 2004 ), multivariate discriminant analysis (MDA) (Kashiwhgi \& Byfield, 2002; Holt, 1998), cash flow techniques, multi-parameters evaluation bidding system, qualifier-1 and qualifier-2 or contractor pre-qualification, highlight optimum legitimate tender (HOLT) selection techniques, program evaluation and review technique (PERT) approach, and decision support systems for contractor prequalification - an artificial neural network approach (Nicholas \& Holt, 2003).

Wong et al. (2002, 2003), Kashiwhgi and Byfield, 2002, Nicholas and Holt (2003) used multivariate techniques to study the intrinsic link between clients' selection preferences, i.e. project-specific criteria (PSC) and their respective levels of importance (LIA), logistic regression (LR) and multivariate discriminant analysis (MDA). They surveyed 68 UK construction projects and reported that all techniques produced a good prediction on contractor performance. Holt et al. $(1993,1995)$ provided an empirical study of multi-attribute analysis for evaluating construction bidders. Furthermore, Holt (1998) reviewed and analyzed the use of various contractor selection techniques and explained the advantages and disadvantages of these methods.

Yasamis et al. (2002) presented a contractor quality performance (CQP) evaluation technique, which can be implemented in a contractor selection strategy. The proposed model was based on a list of CQP indicators extracted from the contractors' records on previously finished projects and their overall performance at corporate level.

Minchin and Smith (2005) proposed a model, called the quality-based performance rating (QBPR) system, for contractor selection. This model receives input from traditional subjective sources and integrates it with objective data input from the results of investigation on a project's materials and workmanship quality. It also uses both to generate a score for each project, which is used by the system to create an index for each contractor reflecting the contractor's quality of work over specified time horizon. Turkis (2008) presented an MCDA method by applying rules of dealing with qualitative and quantitative information as well as with data expressed in words in terms of verbal data.

Many models have been developed for contractor selection decisions, are based on rather simplistic perceptions of MCDM techniques (Demirtas \& Stun, 2008; Cheng and Li, 2004). Comprehensive MCDM techniques have been implemented for the contractor selection process. They have been changed into computer expert systems and implemented in designing and building projects (Luu et al. 2003). MCDM as well as AHP and analytic network process (ANP) methods are comprehensive decision-making techniques (Huang \& Keskar, 2007). To handle tangible as well as intangible criteria, there are many applications of AHP and ANP for constructor selection. The hierarchical structure of the AHP model can help users visualize the problem systematically in terms of criteria and sub-criteria. Besides, the user can compare and determine the priorities of the criteria and alternatives effectively. (Demirtas and Stun, 2008). Nevertheless, many researchers have concerns about the mathematical rigor of AHP (Huang \& Keskar, 2007). ANP, however, is a more general form of AHP. In AHP, a decision is pursued using a unidirectional hierarchical relationship among 
the decision levels, whereas ANP is used to evaluate a dynamic multi-directional relationship among the decision attributes (Mohantry et al. 2005). Although ANP can capture the interdependencies between the criteria under consideration, it has its own disadvantages. One of the limitations in ANP is that it needs more comparisons than the AHP, which makes it time consuming and frustrating. However, complex decisions may need such complex technique. Another limitation might exist in case there are different alternatives in decision model. In terms of making a number of pair-wise comparisons, it would be interesting (Bayazi, 2006). ANP requires more calculations and formation of additional pair-wise comparison matrices compared with the AHP process. (Ravi et al. 2005).

\subsection{Considered criteria}

Inappropriate criteria choice is the prime cause of inadequate contractor selection. Correct importance of criteria and selection of suitable techniques are equally important (Banaitienê \& Banaitis, 2006). The efficiency of a construction process is normally associated with the successful choice of a contractor (Hatush \& Skitmore, 1998). During the past few years, the predominant procurement process in construction has been the competitive "low-bid" procurement process, which has encouraged an increase in the pressure on price, proliferation of construction systems and products to meet the minimum requirements, more pushes for contractors to generate greater volume, and construction non-performance and litigation. The low-bid process has not produced the results facility owners, require. It has produced low-quality work, adversarial working circumstances, a high incidence of contractor-generated change orders, claims, litigation and increased project management costs, and this has nothing to do with quality. No one is interested in the system, but everyone understands it (Kashiwhgi \& Byfield, 2002).

The construction industry is dynamic in nature and the concept of project success has remained ambiguously defined. The success of construction project is almost the ultimate objective for every project but the definition is completely vague (Chan \& Chan, 2004). In practice, there are different procedures for contractor selection and all of them are aimed at choosing a qualified contractor on a competitive basis, but in reality a decision is usually based on a single criterion (Hatush \& Skitmore, 1998). Therefore, price criterion is a decisive in contractor selection. Lately the "lowest bid" selection practice has been argued since it involves high-risk exposure of the client. The selection based on the low price basis is one of the reasons for project completion delays, poor quality and/or financial losses, etc. An offered bid price is an important item in choosing a contractor, but there are many other important issues, which are important in project implementation, which have to be in the contractor's evaluation process (Hatush \& Skitmore, 1998; Zavadaskas \& Vilutiene, 2006).

The increase emphasis directed towards encouraging lowest bid price requires to be redirected towards establishing contractor's ability to reach project owner's satisfaction by providing high project performance (time) and high quality of completed product (Holt et al. 1995). The outcome of a construction project is measured in terms of cost, time, and quality achieved. Therefore, these are three main concepts for contractor selection procedure (Holt, 1998). Based on these main concepts, a list of criteria can be prepared and these criteria are utilized at contractor's prequalification, which is another frequently implemented procedure of choosing contractors ( $\mathrm{Ng} \&$ Skitmore, 1999). As stated, qualified contractors from a group of interested applicants are chosen in terms of their prequalification criteria (Ng \& Skitmore, 1999; Palaneeswaran \& Kumaraswamy, 2001).

There are other contractor selection methods based on the assumption that information on tenders exists during the decision making process of the client. However, this assumption is only applicable where there are experienced developers of large-scale works or with the advice of building consultants who provide the necessary data on the present status and the past performance of each contractor at a relatively low cost of required data. They may even have their own data obtained from the previous contractors. It becomes necessary to build prequalification lists of contractors and quantitative measures of contractors' performance (Luu et al., 2003). Latham defended a 
prequalification system for contractor selection and Egan recommended selection partners based on quantitative techniques of contractor performance (Luu et al. 2003). Paleneeswaran and Kumaraswamy (2001) explained details of "mandatory" prequalification criteria as well as "additional" and "reserved" criteria suggested by construction industry development agency. These are finance, human resources, organization and management, project specific requirements, past experience, past performance, technology, quality system, health and safety system, and equipment. Weightings are assigned to represent the relative importance of these criteria and various scores are assessed for each criterion.

$\mathrm{Ng}$ and Skitmore (1999) introduced the divergence of decision criteria implemented by various clients and consultant organizations in contractor prequalification based on an empirical survey conducted in UK and the result of their investigation determined 35 prequalification criteria. According to the results of the survey, the top 10 prequalification criteria stated by the governmental authorities are as follows: financial stability, performance, fraudulent action, contract failure, corporate stability, progress of work, health and safety, previous debarment, competitiveness and quality standard. The managerial capability criterion found important by other respondent groups is not included in this top 10 list. They chose two factors, which are likely to impact the choice of criteria, which are client objectives and decision maker perceptions.

The contractor's quality performance is another important criteria for client satisfaction (Palaneeswaran \& Kumaraswamy, 2001). The clients' aims are normally associated with cost, time and quality and on the basis of these main aspects, a list of a criteria can be generated. Numerous researchers (Russell et al. 1992; Ng \& Skitmore, 1999; Wong et al. 2000; Molenaar \& Johnson, 2003; Topcu, 2004; Jaselskis \& Russell, 1992; Crowley \& Hancher, 1995; Kumaraswamy, 1996; Juan et al. 2009; Lam et al. 2009; Jaskowski, 2008; Jaskowski \& Sobotka, 2006; Lam et al. 2005; Russell \& Skibniewski, 1990; Singh, \& Tiong, 2006) identified different criteria, which are common among various projects and proposed methodologies for selecting contractors.

\section{Current situation in Iran}

All construction project owners in Iranian public sector use the same contractor selection method as stated in the decree by deputy of technical affairs in the management and planning organization. This organization now has merged into the Islamic Republic of Iran's presidency and presently known as the president deputy strategic planning and control but the deputy of technical affairs and their decrees has not changed.

"Lowest bidder" is selected in Iran but the selection in Australia is based on different criteria and prequalification of all contractors and lowest price mechanism and contractors must meet the mandatory requirements. The primary objective of prequalification is to choose contractors, which are technically able and financially secure. Therefore, measuring and judging potential contractors is adjusted with a set of decision criteria called prequalification criteria (PQC).

Firstly, applicants are evaluated and scared with respect to nine basic prequalification criteria including "Financial stability", "Work Experience", "Technology and equipments", "Experience and knowledge of the technical staff", "Quality", "Management", "Reputation" and "Creativity and innovation", "Being familiar with the area or being domestic". Table 1 shows these criteria and their corresponding weights, for each main criteria. There are limitations for the points and when they put out to tender, the project owners provide a unique value between these limits. 
Table 1

Standard prequalification criteria and weights

\begin{tabular}{|c|c|c|c|c|c|c|c|c|c|c|}
\hline Criteria & $\begin{array}{l}\Omega \\
\stackrel{\Xi}{0} \\
\hat{\Xi} \\
\stackrel{\Xi}{\Xi} \\
\stackrel{\Xi}{\Xi}\end{array}$ & 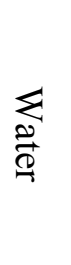 & 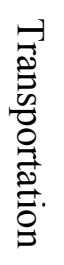 & $\begin{array}{l}\vec{\Xi} \\
\stackrel{\vec{Z}}{E} \\
\text { 芝 }\end{array}$ & 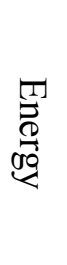 & 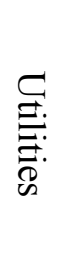 & $\begin{array}{l}0 \\
0 \\
0 \\
0 \\
0 \\
\mathscr{0}\end{array}$ & 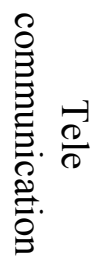 & 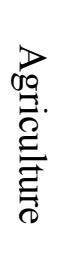 & 胥 \\
\hline \multirow{2}{*}{ Work experience } & 10 & 10 & 10 & 10 & 10 & 10 & 10 & 10 & 10 & 10 \\
\hline & 20 & 20 & 20 & 20 & 20 & 20 & 20 & 20 & 20 & 20 \\
\hline \multirow{2}{*}{ Technology and equipments } & 10 & 10 & 20 & 5 & 10 & 5 & 20 & 0 & 10 & 10 \\
\hline & 20 & 20 & 30 & 10 & 20 & 10 & 40 & 5 & 20 & 20 \\
\hline \multirow{2}{*}{ Management } & 2 & 2 & 2 & 2 & 2 & 2 & 2 & 2 & 2 & 2 \\
\hline & 5 & 5 & 5 & 5 & 5 & 5 & 5 & 5 & 5 & 5 \\
\hline \multirow{2}{*}{$\begin{array}{c}\text { Experience and knowledge of the operation } \\
\text { team }\end{array}$} & 10 & 10 & 10 & 10 & 10 & 10 & 10 & 10 & 10 & 10 \\
\hline & 20 & 20 & 20 & 20 & 20 & 20 & 20 & 20 & 20 & 20 \\
\hline \multirow{2}{*}{ Financial stability } & 20 & 20 & 20 & 20 & 20 & 20 & 20 & 20 & 20 & 20 \\
\hline & 30 & 30 & 30 & 30 & 30 & 30 & 30 & 30 & 30 & 30 \\
\hline \multirow{2}{*}{ Quality } & 5 & 5 & 5 & 10 & 5 & 10 & 5 & 15 & 5 & 5 \\
\hline & 10 & 10 & 10 & 20 & 10 & 20 & 10 & 20 & 10 & 10 \\
\hline \multirow{2}{*}{ Being familiar with the area or being domestic } & 10 & 10 & 10 & 0 & 0 & 5 & 10 & 5 & 10 & 20 \\
\hline & 20 & 20 & 20 & 10 & 10 & 10 & 20 & 10 & 20 & 30 \\
\hline \multirow{2}{*}{ Reputation } & 10 & 10 & 10 & 10 & 10 & 10 & 10 & 10 & 10 & 10 \\
\hline & 10 & 10 & 10 & 10 & 10 & 10 & 10 & 10 & 10 & 10 \\
\hline \multirow{2}{*}{ Creativity and innovation } & 5 & 5 & 5 & 5 & 5 & 5 & 5 & 5 & 5 & 5 \\
\hline & 15 & 15 & 15 & 15 & 15 & 15 & 15 & 15 & 15 & 15 \\
\hline
\end{tabular}

100 points is the maximum score for ideal contractor, which gets at the prequalification stage and the threshold value for elimination is 65 , for criteria $2,4,5$ minimum of $40 \%$ is needed. Respecting the main criteria, to calculate the score of application, management and planning organization proposed simple additive weighting method (SAW). Hwang and Yoon (1981) referred the decision maker (DM) assigns importance weights to each of the property in SAW, which becomes the coefficients of the variables. By multiplying the scale rating for each attribute value by the importance weigh and then summing these products over all attributes, DM obtains a total score for each alternative. SAW is very powerful method among MADM techniques.

\section{An integrated VIKOR and AHP methodology}

Basic definitions of fuzzy sets (Chen, 2000):

A fuzzy number is a fuzzy subset in the universe of discourse $X$ that is both convex and normal. Fig. 1 shows a fuzzy number $\tilde{\tau}$ of the universe of discourse $\mathrm{X}$ which is both convex and normal.

The $\propto$-cut of a fuzzy number $\tilde{\tau}$ is defined,

$\tilde{\tau}^{\propto}=\left\{x_{i}: \mu_{\tau}\left(\left(x_{i}\right)\right) \geq \propto, x_{i} \in X\right\}$,

where $\lambda \in[0,1], \tilde{\tau}$ is a non-empty bounded closed interval contained in $X$ and it can be denoted by $\tilde{\boldsymbol{\tau}}^{\alpha}=\left[\tau_{1}^{\alpha}, \tau_{\mathrm{u}}^{\alpha}\right]$, and $\tau_{1}^{\alpha}$ and $\tau_{u}^{\alpha}$ are the lower and upper bounds of the closed interval, respectively. 


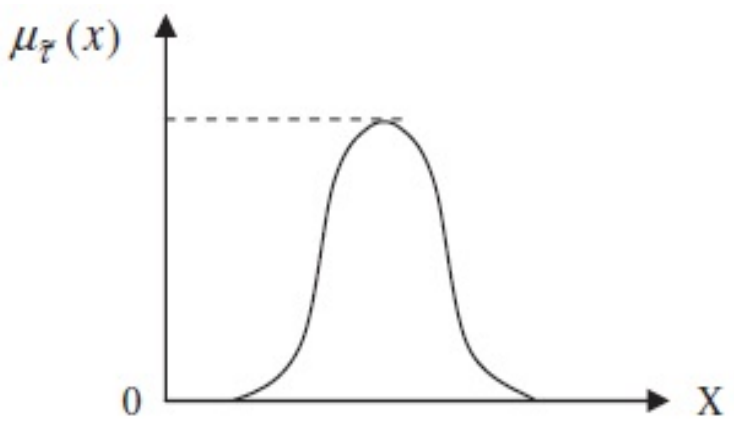

Fig 1. A fuzzy number $\tilde{\tau}$

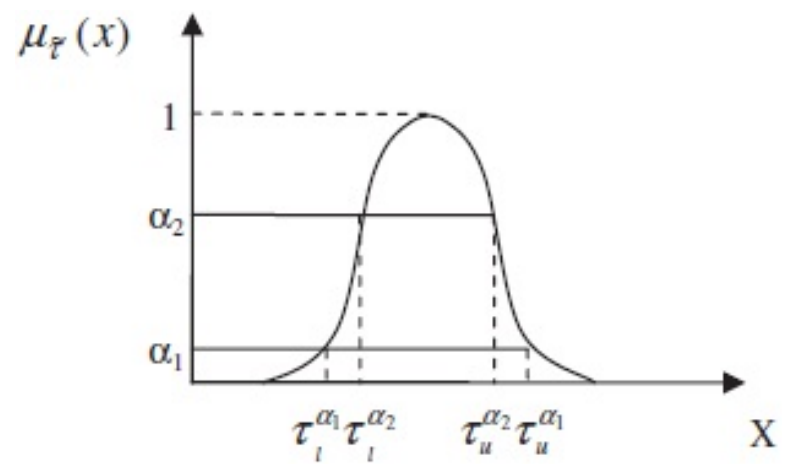

Fig. 2. Fuzzy number $\tilde{\tau}$ with $\propto$-cuts

Fig. 2 shows a fuzzy number $\tilde{\tau}$ with $\propto$-cut, where

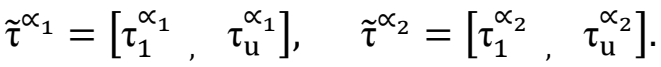

From Fig. 2, we can see that if $\propto_{2} \geq \propto_{1}$, then $\tau_{1}^{\alpha_{2}} \geq \tau_{1}^{\alpha_{1}}$ and $\tau_{u}^{\alpha_{1}} \geq \tau_{u}^{\alpha_{2}}$. A triangular fuzzy number (TFN) $\tilde{\boldsymbol{\tau}}$ defined by a triplet $\left(\mathrm{t}_{1}, \mathrm{t}_{2}, \mathrm{t}_{3}\right)$ as Fig. 3. The membership function $\boldsymbol{\mu}_{\tilde{\tau}}(\mathrm{x})$ is defined as in Eq. (3),

$\mu_{i}(x)=\left\{\begin{array}{cc}0 & x_{1} \leq \tau_{1} \\ \frac{x-\tau_{1}}{\tau_{2}-\tau_{1}} & \tau_{1} \leq x \leq \tau_{2} \\ \frac{x-\tau_{3}}{\tau_{2}-\tau_{3}} & \tau_{2} \leq x \leq \tau_{3} \\ 0 & x \geq \tau_{3}\end{array}\right.$

If $\tilde{\boldsymbol{\tau}}$ is a fuzzy number and $\tau_{1}{ }^{\alpha}>0$ for $\alpha \in[0,1]$, then $\tilde{\boldsymbol{\tau}}$ is positive fuzzy number with two positive fuzzy numbers $\tilde{\rho}, \tilde{\tau}$ and a positive real number $\mathrm{r}$, the $\propto$-cut of two fuzzy numbers are $\tilde{\rho}^{\alpha}=\left[\rho_{1}^{\alpha}, \rho_{\mathrm{u}}^{\alpha}\right]$ and $\tilde{\boldsymbol{\tau}}^{\alpha}=\left[\tau_{1}^{\alpha}, \tau_{u}^{\alpha}\right](\alpha \in[0,1])$ respectively. As interval of confidence, some basic operations of positive fuzzy numbers $\tilde{\rho}$ and $\tilde{\tau}$ can be expressed as follows (Kaufmann \& Gupta, 1985):

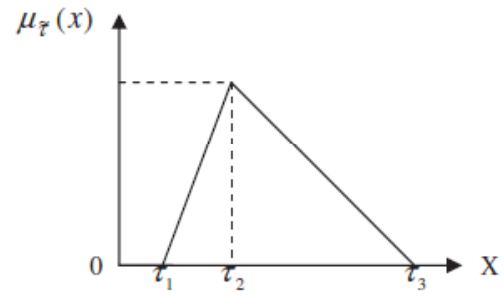

Fig. 3. A triangular fuzzy number $\tilde{\tau}$

$$
\begin{aligned}
& (\tilde{\rho}(+) \tilde{\mathrm{t}})^{\alpha}=\left[\rho_{1}^{\alpha}+\tau_{1}^{\alpha}, \rho_{\mathrm{u}}^{\alpha}+\tau_{\mathrm{u}}^{\alpha}\right], \\
& (\tilde{\rho}(-) \tilde{\mathrm{t}})^{\alpha}=\left[\rho_{1}^{\alpha}-\tau_{\mathrm{u}}^{\alpha}, \rho_{\mathrm{u}}^{\alpha}-\tau_{1}^{\alpha}\right], \\
& (\tilde{\rho}(.) \tilde{\mathrm{t}})^{\alpha}=\left[\rho_{1}^{\alpha} \cdot \tau_{1}^{\alpha}, \rho_{\mathrm{u}}^{\alpha} \cdot \tau_{\mathrm{u}}^{\alpha}\right], \\
& (\tilde{\rho}(.) \tilde{\mathrm{t}})^{\alpha}=\left[\frac{\rho_{1}^{\alpha}}{\tau_{\mathrm{u}}^{\alpha}}, \frac{\rho_{\mathrm{u}}^{\alpha}}{\tau_{1}^{\alpha}}\right],
\end{aligned}
$$


$\left(\tilde{\rho}^{\alpha}\right)^{-1}=\left[\frac{1}{\rho_{\mathrm{u}}^{\alpha}}, \frac{1}{\rho_{1}^{\alpha}}\right]$,

$(\tilde{\rho}(.) r)^{\alpha}=\left[\rho_{1}^{\alpha} \cdot r, \rho_{u}^{\alpha} \cdot r\right]$,

$(\tilde{\rho}(:) r)^{\alpha}=\left[\frac{\rho_{1}^{\alpha}}{r}, \frac{\rho_{u}^{\alpha}}{r}\right]$.

If $\tilde{n}$ is a triangular fuzzy number and $\tau_{1}^{\alpha}>0, \tau_{u}^{\alpha} \leq 1$ for $\alpha \in[0,1]$, then $\tilde{\boldsymbol{\tau}}$ is called a normalized positive triangular fuzzy number (Zimmermann, 1991). Fuzzy numbers are indicators of linguistic values. Linguistic variable values are linguistic terms (Zadeh, 1975). To evaluate the importance of the criteria, decision makers use the Linguistic variables. A modified fuzzy approach to the classical VIKOR is proposed in this section. The importance weight of each criterion can be obtained by either directly assigning or indirectly using pairwise comparisons. Here, it is recommended where the decision makers use the linguistic variables in Table 2 to evaluate the importance of the criteria. Wang et al. (2006) calculated the weight of each criterion by summing the assigned weights by experts and then dividing the sum by the number of experts as in Eq. (11),

$$
\widetilde{w}_{i j}=\frac{1}{K}\left[\widetilde{w}_{j}^{1}(+) \widetilde{w}_{j}^{2}(+) \ldots(+) \widetilde{w}_{j}^{k}\right]
$$

where $\widetilde{w}_{j}{ }^{k}$ is the relative importance weight of the $K^{\text {th }}$ decision maker. Since a comparison matrix divides the problem into sub-problems, which can be solved easier, a pairwise comparison matrix in the AHP method is a good way to determine weights of criteria, since a comparison matrix divides the problem into sub-problems. By listing fuzzy comparison matrices, we can modify the classical weighting method of VIKOR methodology. Chang (1996) extent analysis will be utilized for this purpose.

Levels of the extent analysis method can be summarized as follows. Let $C_{j}=\left\{C_{1}, C_{2}, \ldots, C_{n}\right\}$ be a criterion set, extent analysis values for each criterion can be obtained as follows: Let $\widetilde{M}_{j}(j=$ $1,2,3, \ldots, n)$ be TFNs. The value of fuzzy synthetic extent for the degree of possibility of $\widetilde{M}_{1} \geq \widetilde{M}_{2}$ is as follows,

$\tilde{s}_{j}=\sum_{j=1}^{n} \widetilde{M}_{j} \otimes\left[\sum_{k=1}^{m} \sum_{j=1}^{n} \widetilde{M}_{j}\right]^{-1}$

In our case, $n=m$ since a comparison matrix for criteria always is a square matrix:

\section{Table 2}

Fuzzy evaluation scores for the weights

\begin{tabular}{lc}
\hline Linguistic terms & Fuzzy score \\
\hline Absolutely strong (AS) & $(2,5 / 2,3)$ \\
Very strong (VS) & $(3 / 2,2,5 / 2)$ \\
Fairly strong (FS) & $(1,3 / 2,2)$ \\
Slightly strong (SS) & $(1,1,3 / 2)$ \\
Equal (E) & $(1,1,1)$ \\
Slightly weak (SW) & $(2 / 3,1,1)$ \\
Fairly weak (FW) & $(1 / 2,2 / 3,1)$ \\
Very weak (VW) & $(2 / 5,1 / 2,2 / 3)$ \\
Absolutely weak (AW) & $(1 / 3,2 / 5,1 / 2)$ \\
\hline
\end{tabular}

$$
V\left(\widetilde{M}_{1} \geq \widetilde{M}_{2}\right)=\sup _{\mathrm{x} \geq \mathrm{y}}\left[\min \left(\mu_{\widetilde{M}_{1}}(x), \mu_{\widetilde{M}_{2}}(y)\right)\right],
$$


where (x,y) exists such that $\mathrm{x} \geq \mathrm{y}$ and $\mu_{\widetilde{M}_{1}}=\mu_{\widetilde{M}_{2}}=1, \quad V\left(\widetilde{M}_{1} \geq \widetilde{M}_{2}\right)=1$ is obtained. The following principle of the comparison of fuzzy numbers is applied since $\widetilde{M}_{1}$ and $\widetilde{M}_{2}$ are convex fuzzy numbers,

$V\left(\widetilde{M}_{1} \geq \widetilde{M}_{2}\right)=1 \quad$ iff $\quad m_{1} \geq m_{2}$,

and

$V\left(\widetilde{M}_{2} \geq \widetilde{M}_{1}\right)=\operatorname{hgt}\left(\widetilde{M}_{1} \cap \widetilde{M}_{2}\right)=\mu(d)$,

where $\mathrm{d}$ is the ordinate of the highest intersection point $\mathrm{D}$ between $\mu_{\widetilde{M}_{1}}$ and $\mu_{\widetilde{M}_{2}}$ when $\widetilde{M}_{1}=$ $\left(l_{1}, m_{1}, u_{1}\right)$ and $\widetilde{M}_{2}=\left(l_{2}, m_{2}, u_{2}\right)$, the following equation for the ordinate of the point $\mathrm{D}$ is given (see Fig.4):

$V\left(\tilde{M}_{2} \geq \tilde{M}_{1}\right)=\operatorname{hgt}\left(\tilde{M}_{2} \cap \tilde{M}_{1}\right)=\left\{\begin{array}{cc}0 & \text { if } m_{2} \geq m_{1} \\ 1 & \text { if } l_{1} \geq u_{2} \\ \frac{l_{2}-u_{2}}{\left(m_{2}-u_{2}\right)-\left(m_{1}-l_{1}\right)} & \text { otherwise }\end{array}\right.$

The values of $V\left(\widetilde{M}_{1} \geq \widetilde{M}_{2}\right)$ and $V\left(\widetilde{M}_{2} \geq \widetilde{M}_{1}\right)$ are obtained by comparing $\widetilde{M}_{1}$ and $\widetilde{M}_{2}$. The degree of possibility for a convex fuzzy number to be greater than $\rho$ convex fuzzy numbers $\left(\widetilde{M}_{j}, \mathrm{j}=1,2,3, \ldots\right.$, n) is defined as:

$$
\begin{aligned}
V\left(\widetilde{M}_{p} \geq \widetilde{M}_{1}, \widetilde{M}_{2}, \ldots, \widetilde{M}_{p-1}, \widetilde{M}_{p+1}, \ldots, \widetilde{M}_{n}\right) \\
\quad=V\left[\left(\widetilde{M}_{p} \geq \widetilde{M}_{1}\right) \text { and }\left(\widetilde{M}_{p} \geq \widetilde{M}_{2}\right) \text { and } \ldots \text { and }\left(\widetilde{M}_{p} \geq \widetilde{M}_{n}\right)\right] \\
\quad=\min V\left(\widetilde{M}_{p} \geq \widetilde{M}_{j}\right)=d\left(c_{j}\right), j \neq p,
\end{aligned}
$$

So, the weight vector $w^{\prime}=\left(d\left(c_{1}\right), \dot{d}\left(c_{2}\right), \ldots, d\left(c_{n}\right)\right)^{T}, \mathrm{j}=1,2,3, \ldots, \mathrm{n}$ is obtained. Finally, via normalization, the following normalized weight vector is obtained:

$$
W=\left(d\left(C_{1}\right), d\left(C_{2}\right), \ldots, d\left(C_{n}\right)\right)^{T} \text {. }
$$

By the weight vector we can implement the stages the VIKOR, which is based on the compromise programming of MCDM. First, Yu (1973) and Zeleny (1982) demonstrated the concepts of compromise solutions. The compromise ranking will be presented by comparing the degree of closeness to ideal one. In fuzzy VIKOR, to evaluate the ratings of alternatives, decision makers use linguistic variables. Table 3 gives the linguistic terms.

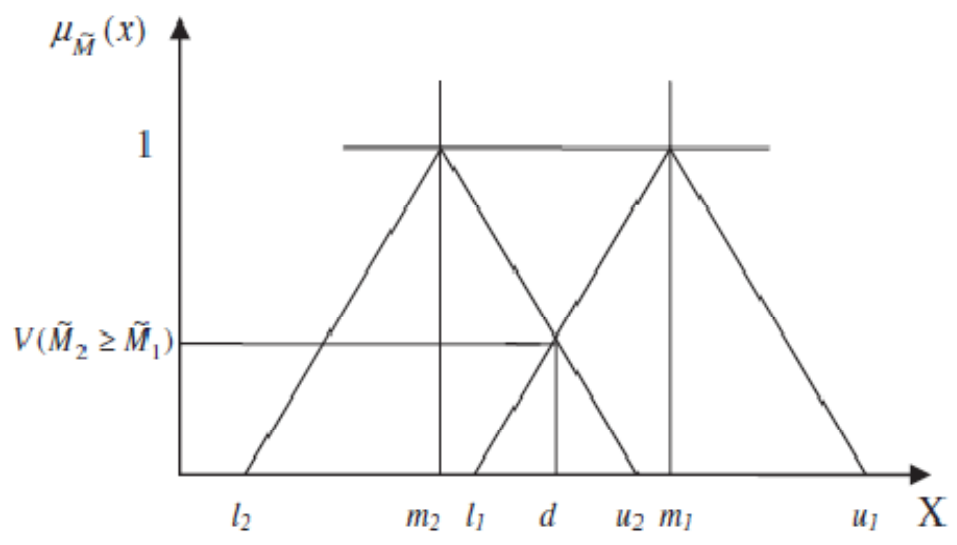

Fig. 4. The intersection between $\widetilde{M}_{1}$ and $\widetilde{M}_{2}$ 


\section{Table 3}

Fuzzy evaluation scores for the alternatives

\begin{tabular}{lc}
\hline Linguistic terms & Fuzzy score \\
\hline Very poor (VP) & $(0,0,1)$ \\
Poor (P) & $(0,1,3)$ \\
Medium poor (MP) & $(1,3,5)$ \\
Fair (F) & $(3,5,7)$ \\
Medium good (MG) & $(5,7,9)$ \\
Good (G) & $(7,9,10)$ \\
Very good (VG) & $(9,10,10)$ \\
\hline
\end{tabular}

If decision group is $K$ people, the ratings of alternatives calculate as in Eq. (19) (Wang et al., 2006),

$\tilde{X}_{i j}=\frac{1}{k}\left[\tilde{x}_{i j}^{1}(+) \tilde{x}_{i j}^{2}(+) \ldots(+) \tilde{x}_{i j}^{k}\right]$,

where $\tilde{x}_{i j}^{k}$ is the rating of the $K^{\text {th }}$ decision maker for $I^{\text {th }}$ alternative with respect to $J^{\text {th }}$ criterion. After obtaining the weights of criteria and fuzzy ratings of alternatives with respect to each criterion, we can express the fuzzy multi-criteria decision-making problem in matrix format as follows,

$$
\begin{array}{r}
\widetilde{D}=\left[\begin{array}{cccc}
\tilde{x}_{11} & \tilde{x}_{12} & \ldots & \tilde{x}_{1 n} \\
\tilde{x}_{21} & \ldots & \ldots & \tilde{x}_{2 n} \\
\tilde{x}_{m 1} & \tilde{x}_{m 2} & \ldots \ldots & \tilde{x}_{m n}
\end{array}\right] \\
W=\left[w_{1}, w_{2}, \ldots, w_{n},\right], \quad j=1,2, \ldots ., n
\end{array}
$$

where $\tilde{X}_{i j}$ is is the rating of the alternative $A_{i}$ with respect to criterion $\mathrm{j}\left(\mathrm{i} . \mathrm{e} . \mathrm{C}_{\mathrm{j}}\right)$ and $\mathrm{w}_{\mathrm{j}}$ denotes the importance weight of $\mathrm{C}_{\mathrm{j}}$. Next step is to determine the fuzzy best value $\left(\mathrm{FBV}, \tilde{f}_{j}^{*}\right)$ and fuzzy worst value $\left(\mathrm{FWV}, \tilde{f}_{j}^{-}\right)$Of all criterion functions:

$\tilde{f}_{j}^{*}=\max _{i} \tilde{x}_{i j}, \quad j \in B ; \quad \tilde{f}_{j}^{-}=\min _{i} \tilde{x}_{i j}, \quad j \in c$.

Then, the values $\widetilde{w}_{j}\left(\tilde{f}_{j}^{*}-\tilde{x}_{i j}\right) /\left(\tilde{f}_{j}^{*}-\tilde{f}_{j}^{-}\right), \tilde{S}_{i}$ and $\tilde{R}_{i}$ are computed as follows,

$\tilde{S}_{i}=\frac{\sum_{j=1}^{n} \widetilde{w}_{j}\left(\tilde{f}_{j}^{*}-\tilde{x}_{i j}\right)}{\tilde{f}_{j}^{*}-\tilde{f}_{j}^{-}}$,

$\tilde{R}_{i}=\max _{j}\left[\widetilde{w}_{j}\left(\tilde{f}_{j}^{*}-\tilde{x}_{i j}\right) /\left(\tilde{f}_{j}^{*}-\tilde{f}_{j}^{-}\right)\right]$

where $\tilde{\boldsymbol{S}}_{\boldsymbol{i}}$ refers to the separation measure of $\mathrm{A}_{\mathrm{i}}$ from the fuzzy best value, and $\tilde{R}_{i}$ to the separation measure of $A_{i}$ from the fuzzy worst value. In the next step, $\tilde{S}^{*}, \tilde{S}^{-}, \tilde{R}^{*}, \tilde{R}^{-}$and $\tilde{Q}_{i}$ values are calculated:

$\tilde{S}^{*}=\min _{i} \tilde{S}_{i}, \quad \tilde{S}^{-}=\max _{i} \tilde{S}_{i}$

$\widetilde{R}^{*}=\min _{i} \tilde{R}_{i}, \quad \widetilde{R}^{-}=\max _{i} \tilde{R}_{i}$

$\tilde{Q}_{i}=v\left(\tilde{S}_{i}-\tilde{S}^{*}\right) /\left(\tilde{S}^{-}-\tilde{S}^{*}\right)+(1-v)\left(\tilde{R}_{i}-\tilde{R}^{*}\right) /\left(\tilde{R}^{-}-\tilde{R}^{*}\right)$.

The index $\min _{i} \tilde{S}_{i}$ and $\min _{i} \tilde{R}_{i}$ are refer to a maximum majority rule, and a minimum individual regret of an opponent strategy, respectively. So , $v$ is introduced as weight of the strategy of the maximum group utility, usually $\boldsymbol{v}$ is assumed to be 0.5 . Next we must use defuzzification of the triangular fuzzy number $\widetilde{Q}_{i}$ and rank the alternatives by the index $\widetilde{Q}_{i}$. Different defuzzification ways 
introduced as the process converting a fuzzy number into a crisp and Graded mean integration is applied here, which is as follows (Yong, 2006),

$\tilde{c}=\left(c_{1}, c_{2}, c_{3}\right), p(\tilde{c})=c=\frac{c_{1}+4 c_{2}+c_{3}}{6}$

With the minimum of $\mathrm{Q}_{\mathrm{i}}$, the best alternative we have.

To summarize the methodology, the steps of the modified fuzzy VIKOR approach are as follows,

Step 1: Decision makers find the evaluation criteria,

Step 2: Important linguistic variables for the weights of the criteria and the alternatives are chosen.

Step 3: To get a mean value for each pair wise comparison, a pair wise comparison matrix for the criteria is constructed and experts' linguistic evaluations are aggregated.

Step 4: To get the weights of the criteria, extent analysis way is used.

Step 5: To get the fuzzy ratings of the alternatives, Linguistic evaluations of the experts are aggregated; this is done with respect to each criteria.

Step 6: Fuzzy decision matrix is made for the implementation of VIKOR.

Step 7: Fuzzy best value (FBV, $\left.\tilde{f}_{j}^{*}\right)$ and fuzzy worst value $\left(\mathrm{FWV}, \tilde{f}_{j}^{-}\right)$of all criteria functions are determined.

Step 8: Separation measures $\left(\tilde{S}_{i}\right.$ and $\left.\tilde{R}_{i}\right)$ are calculated.

Step 9: $\widetilde{Q}_{i}$ values are calculated.

Step 10: $\widetilde{Q}_{i}$ values are defuzzified and the alternatives are ranked by the index $Q_{i}$.

Step 11: The best alternative with the minimum of $\mathrm{Q}_{\mathrm{i}}$ is determined.

\section{An application: contractor selection in one of Iran construction industry projects}

To evaluate the alternative contractor in this study, the criteria are as:

Work experience $(\mathrm{C} 1)$ : Contractor work experience assess based on information about the number and type of work in the related fields, in the past five years.

Financial stability (C2): Financial stability of contractors is assessed during the past five years, which would be determined as follows:

- The average tax paid per year,

- Insurance firm paid,

- The annual net income,

- Fixed assets that certify from legal offices,

- Financial certificate from a bank or financial and credit institution.

Quality (C3): This criterion is calculated based on the quality of previous work done by the contractor, having international quality certificates such as ISO series of standards, etc.

Management (C4): This criterion is evaluated based on the number of managers, degree and field of study of managers, and work experience inside and outside the company.

Technology and equipments (C5): This criterion is calculated according to information provided on the machine. 
Experience and knowledge of the operation team (C6): This criterion is evaluated based on the number of staff positions, degree and field of study of personnel, and work experience inside and outside the company.

Reputation (C7): Professional reputation is important for all businesses. But for government contractors, reputation in the form of past performance information often makes the difference between winning or losing a contract, which can be measured by contractor documents of previous taskmasters recommendation. This will help to ensure they will not disappear or declare bankruptcy before the project is completed.

Being familiar with the area or being domestic (C8): This criterion is measured based on quantity, and quality of projects done, and recognition special features of the area by contractor.

Creativity and innovation (C9): Innovative and creative works are performed on previous projects.

After getting the evaluation criteria and the alternatives, the integrated fuzzy VIKOR-AHP algorithm is employed. To assess the relative importance of each evaluation criterion, the experts used a nine scale as given in Table 2. Each term is associated with triangular fuzzy number, so making arithmetical operations with linguistic terms is impossible. The results of the pair wise comparisons of the evaluation criteria are given in Table 4.

With Table 2 and Table 4, in the next step, the fuzzy evaluation matrix for the criteria weights is calculated as Table 5. To obtain this matrix, the arithmetic means of the fuzzy scores in are calculated. Then, to check the consistency ratio (CR) of the evaluation matrix, for defuzzification is used of graded mean integration approach (Eq. 26). CR for the defuzzified version of the evaluation matrix is calculated as 0.019 and it is less than 0.10 . So, the comparison results can be considered consistent and appropriate for an AHP method. Then, by Eq. (12) fuzzy synthetic extent values $\left(\tilde{S}_{i}\right)$ for the evaluation criteria are produced. After having the synthetic extent values, Eqs. (13)-(17) are used to calculate the weight vector.

Table 4

Pair-wise comparisons of evaluation criteria

\begin{tabular}{|c|c|c|c|c|c|c|c|c|c|}
\hline & $\mathrm{C}_{1}$ & $\mathrm{C}_{2}$ & $\mathrm{C}_{3}$ & $\mathrm{C}_{4}$ & $\mathrm{C}_{5}$ & $\mathrm{C}_{6}$ & $\mathrm{C}_{7}$ & $\mathrm{C}_{8}$ & $\mathrm{C}_{9}$ \\
\hline \multirow[t]{3}{*}{$\mathrm{C}_{1}$} & 1 & $\mathrm{E}_{1}: \mathrm{SS}$ & $\mathrm{E}_{1}: \mathrm{AS}$ & $\mathrm{E}_{1}$ : VS & $\mathrm{E}_{1}: \mathrm{SS}$ & $\mathrm{E}_{1}: \mathrm{FS}$ & $\mathrm{E}_{1}: \mathrm{VS}$ & $\mathrm{E}_{1}: \mathrm{VS}$ & $\mathrm{E}_{1}: \mathrm{FS}$ \\
\hline & & $\mathrm{E}_{2}: \mathrm{SS}$ & $\mathrm{E}_{2}: \mathrm{E}$ & $\mathrm{E}_{2}: \mathrm{SW}$ & $\mathrm{E}_{2}: \mathrm{SS}$ & $\mathrm{E}_{2}: \mathrm{FS}$ & $\mathrm{E}_{2}: \mathrm{E}$ & $\mathrm{E}_{2}: \mathrm{E}$ & $\mathrm{E}_{2}: \mathrm{FS}$ \\
\hline & & $\mathrm{E}_{3}: \mathrm{SW}$ & $\mathrm{E}_{3}: \mathrm{SW}$ & $E_{3}: E$ & $\mathrm{E}_{3}: \mathrm{SS}$ & $\mathrm{E}_{3}: \mathrm{SW}$ & $\mathrm{E}_{3}: \mathrm{SS}$ & $E_{3}: E$ & $E_{3}: E$ \\
\hline \multirow[t]{3}{*}{$\mathrm{C}_{2}$} & $\mathrm{E}_{1}: \mathrm{SW}$ & 1 & $\mathrm{E}_{1}: \mathrm{FS}$ & $\mathrm{E}_{1}: \mathrm{FS}$ & $\mathrm{E}_{1}: \mathrm{E}$ & $\mathrm{E}_{1}: \mathrm{SS}$ & $\mathrm{E}_{1}: \mathrm{FS}$ & $\mathrm{E}_{1}: \mathrm{FS}$ & $\mathrm{E}_{1}: \mathrm{ES}$ \\
\hline & $\mathrm{E}_{2}: \mathrm{SW}$ & & $\mathrm{E}_{2}: \mathrm{SW}$ & $\mathrm{E}_{2}: \mathrm{FW}$ & $\mathrm{E}_{2}: \mathrm{E}$ & $\mathrm{E}_{2}: \mathrm{SS}$ & $\mathrm{E}_{2}: \mathrm{SW}$ & $\mathrm{E}_{2}: \mathrm{SW}$ & $\mathrm{E}_{2}: \mathrm{SS}$ \\
\hline & $\mathrm{E}_{3}: \mathrm{SS}$ & & $\mathrm{E}_{3}: \mathrm{E}$ & $\mathrm{E}_{3}: \mathrm{SS}$ & $\mathrm{E}_{3}: \mathrm{FS}$ & $\mathrm{E}_{3}: \mathrm{E}$ & $\mathrm{E}_{3}: \mathrm{FS}$ & $\mathrm{E}_{3}: \mathrm{SS}$ & $\mathrm{E}_{3}: \mathrm{SS}$ \\
\hline \multirow[t]{3}{*}{$\mathrm{C}_{3}$} & $\mathrm{E}_{1}: \mathrm{AW}$ & $\mathrm{E}_{1}: \mathrm{FW}$ & 1 & $\mathrm{E}_{1}: \mathrm{SS}$ & $\mathrm{E}_{1}: \mathrm{FW}$ & $\mathrm{E}_{1}: \mathrm{SW}$ & $\mathrm{E}_{1}: \mathrm{E}$ & $\mathrm{E}_{1}: \mathrm{E}$ & $\mathrm{E}_{1}: \mathrm{SW}$ \\
\hline & $\mathrm{E}_{2}: \mathrm{E}$ & $\mathrm{E}_{2}: \mathrm{SS}$ & & $\mathrm{E}_{2}: \mathrm{SW}$ & $\mathrm{E}_{2}: \mathrm{SS}$ & $\mathrm{E}_{2}: \mathrm{FS}$ & $E_{2}: E$ & $\mathrm{E}_{2}: \mathrm{E}$ & $\mathrm{E}_{2}: \mathrm{FS}$ \\
\hline & $\mathrm{E}_{3}: \mathrm{SS}$ & $\mathrm{E}_{3}: \mathrm{E}$ & & $\mathrm{E}_{3}: \mathrm{SS}$ & $\mathrm{E}_{3}: \mathrm{FS}$ & $\mathrm{E}_{3}: \mathrm{E}$ & $\mathrm{E}_{3}: \mathrm{FS}$ & $\mathrm{E}_{3}: \mathrm{SS}$ & $\mathrm{E}_{3}: \mathrm{SS}$ \\
\hline \multirow[t]{3}{*}{$\mathrm{C}_{4}$} & $\mathrm{E}_{1}: \mathrm{VW}$ & $\mathrm{E}_{1}: \mathrm{FW}$ & $\mathrm{E}_{1}: \mathrm{SW}$ & 1 & $\mathrm{E}_{1}: \mathrm{FW}$ & $\mathrm{E}_{1}: \mathrm{SW}$ & $\mathrm{E}_{1}: \mathrm{E}$ & $\mathrm{E}_{1}: \mathrm{E}$ & $E_{1}: S W$ \\
\hline & $\mathrm{E}_{2}: \mathrm{SS}$ & $\mathrm{E}_{2}: \mathrm{FS}$ & $\mathrm{E}_{2}: \mathrm{SS}$ & & $E_{2}: F S$ & $E_{2}: V S$ & $\mathrm{E}_{2}: \mathrm{SS}$ & $\mathrm{E}_{2}: \mathrm{SS}$ & $\mathrm{E}_{2}: \mathrm{AS}$ \\
\hline & $E_{3}: E$ & $E_{3}: S W$ & $\mathrm{E}_{3}: \mathrm{SW}$ & & $\mathrm{E}_{3}: \mathrm{SW}$ & $E_{3}: S W$ & $\mathrm{E}_{3}: \mathrm{SS}$ & $E_{3}: E$ & $E_{3}: E$ \\
\hline \multirow[t]{3}{*}{$\mathrm{C}_{5}$} & $\mathrm{E}_{1}: \mathrm{SW}$ & $E_{1}: E$ & $\mathrm{E}_{1}: \mathrm{FS}$ & $\mathrm{E}_{1}: \mathrm{FS}$ & 1 & $\mathrm{E}_{1}: \mathrm{SS}$ & $\mathrm{E}_{1}: \mathrm{FS}$ & $\mathrm{E}_{1}: \mathrm{FS}$ & $\mathrm{E}_{1}: \mathrm{SS}$ \\
\hline & $\mathrm{E}_{2}: \mathrm{SW}$ & $\mathrm{E}_{2}: \mathrm{E}$ & $\mathrm{E}_{2}: \mathrm{SW}$ & $\mathrm{E}_{2}: \mathrm{FW}$ & & $\mathrm{E}_{2}: \mathrm{SS}$ & $\mathrm{E}_{2}: \mathrm{SW}$ & $\mathrm{E}_{2}: \mathrm{SW}$ & $\mathrm{E}_{2}: \mathrm{SS}$ \\
\hline & $\mathrm{E}_{3}: \mathrm{SW}$ & $\mathrm{E}_{3}: \mathrm{FW}$ & $\mathrm{E}_{3}: \mathrm{FW}$ & $\mathrm{E}_{3}: \mathrm{SS}$ & & $\mathrm{E}_{3}: \mathrm{FW}$ & $\mathrm{E}_{3}: \mathrm{SW}$ & $\mathrm{E}_{3}: \mathrm{SW}$ & $\mathrm{E}_{3}: \mathrm{SW}$ \\
\hline \multirow[t]{3}{*}{$\mathrm{C}_{6}$} & $\mathrm{E}_{1}: \mathrm{FW}$ & $E_{1}: S W$ & $\mathrm{E}_{1}: \mathrm{SS}$ & $\mathrm{E}_{1}: \mathrm{SS}$ & $E_{1}: S W$ & 1 & $\mathrm{E}_{1}: \mathrm{SS}$ & $\mathrm{E}_{1}: \mathrm{SS}$ & $E_{1}: E$ \\
\hline & $\mathrm{E}_{2}: \mathrm{FW}$ & $\mathrm{E}_{2}: \mathrm{SW}$ & $\mathrm{E}_{2}: \mathrm{FW}$ & $\mathrm{E}_{2}: \mathrm{VW}$ & $\mathrm{E}_{2}: \mathrm{SW}$ & & $\mathrm{E}_{2}: \mathrm{FW}$ & $\mathrm{E}_{2}: \mathrm{FW}$ & $\mathrm{E}_{2}: \mathrm{E}$ \\
\hline & $\mathrm{E}_{3}: \mathrm{SS}$ & $\mathrm{E}_{3}: \mathrm{E}$ & $\mathrm{E}_{3}: \mathrm{E}$ & $\mathrm{E}_{3}: \mathrm{SS}$ & $\mathrm{E}_{3}$ : FS & & $\mathrm{E}_{3}: \mathrm{FS}$ & $\mathrm{E}_{3}: \mathrm{SS}$ & $\mathrm{E}_{3}: \mathrm{SS}$ \\
\hline \multirow[t]{3}{*}{$\mathrm{C}_{7}$} & $\mathrm{E}_{1}: \mathrm{VW}$ & $\mathrm{E}_{1}: \mathrm{FW}$ & $\mathrm{E}_{1}: \mathrm{E}$ & $\mathrm{E}_{1}: \mathrm{E}$ & $\mathrm{E}_{1}: \mathrm{FW}$ & $\mathrm{E}_{1}: \mathrm{SW}$ & 1 & $\mathrm{E}_{1}: \mathrm{E}$ & $\mathrm{E}_{1}: \mathrm{SW}$ \\
\hline & $\mathrm{E}_{2}: \mathrm{E}$ & $\mathrm{E}_{2}: \mathrm{SS}$ & $\mathrm{E}_{2}: \mathrm{E}$ & $\mathrm{E}_{2}: \mathrm{SW}$ & $\mathrm{E}_{2}: \mathrm{SS}$ & $\mathrm{E}_{2}: \mathrm{FS}$ & & $\mathrm{E}_{2}: \mathrm{E}$ & $\mathrm{E}_{2}: \mathrm{FS}$ \\
\hline & $\mathrm{E}_{3}: \mathrm{SW}$ & $\mathrm{E}_{3}: \mathrm{FW}$ & $\mathrm{E}_{3}: \mathrm{FW}$ & $\mathrm{E}_{3}: \mathrm{SW}$ & $\mathrm{E}_{3}: \mathrm{SS}$ & $\mathrm{E}_{3}: \mathrm{FW}$ & & $\mathrm{E}_{3}: \mathrm{SW}$ & $\mathrm{E}_{3}: \mathrm{SW}$ \\
\hline \multirow[t]{3}{*}{$\mathrm{C}_{8}$} & $\mathrm{E}_{1}: \mathrm{VW}$ & $\mathrm{E}_{1}: \mathrm{FW}$ & $\mathrm{E}_{1}: \mathrm{E}$ & $E_{1}: E$ & $\mathrm{E}_{1}: \mathrm{FW}$ & $\mathrm{E}_{1}: \mathrm{SW}$ & $\mathrm{E}_{1}: \mathrm{E}$ & 1 & $E_{1}: S W$ \\
\hline & $E_{2}: E$ & $\mathrm{E}_{2}: \mathrm{SS}$ & $\mathrm{E}_{2}: \mathrm{E}$ & $\mathrm{E}_{2}: \mathrm{SW}$ & $\mathrm{E}_{2}: \mathrm{SS}$ & $\mathrm{E}_{2}: \mathrm{FS}$ & $E_{2}: E$ & & $\mathrm{E}_{2}: \mathrm{FS}$ \\
\hline & $\mathrm{E}_{3}: \mathrm{E}$ & $\mathrm{E}_{3}: \mathrm{SW}$ & $\mathrm{E}_{3}: \mathrm{SW}$ & $\mathrm{E}_{3}: \mathrm{E}$ & $\mathrm{E}_{3}: \mathrm{SS}$ & $\mathrm{E}_{3}: \mathrm{SW}$ & $\mathrm{E}_{3}: \mathrm{SS}$ & & $\mathrm{E}_{3}: \mathrm{E}$ \\
\hline \multirow[t]{3}{*}{$\mathrm{C}_{9}$} & $E_{1}: F W$ & $\mathrm{E}_{1}: \mathrm{SW}$ & $\mathrm{E}_{1}: \mathrm{SS}$ & $\mathrm{E}_{1}: \mathrm{SS}$ & $\mathrm{E}_{1}: \mathrm{SW}$ & $E_{1}: E$ & $\mathrm{E}_{1}: \mathrm{SS}$ & $\mathrm{E}_{1}: \mathrm{SS}$ & 1 \\
\hline & $\mathrm{E}_{2}: \mathrm{FW}$ & $\mathrm{E}_{2}: \mathrm{SW}$ & $\mathrm{E}_{2}: \mathrm{FW}$ & $\mathrm{E}_{2}: \mathrm{AW}$ & $\mathrm{E}_{2}: \mathrm{SW}$ & $\mathrm{E}_{2}: \mathrm{E}$ & $\mathrm{E}_{2}: \mathrm{FW}$ & $\mathrm{E}_{2}: \mathrm{FW}$ & \\
\hline & $\mathrm{E}_{3}: \mathrm{E}$ & $\mathrm{E}_{3}: \mathrm{SW}$ & $\mathrm{E}_{3}: \mathrm{SW}$ & $\mathrm{E}_{3}: \mathrm{E}$ & $\mathrm{E}_{3}: \mathrm{SS}$ & $\mathrm{E}_{3}: \mathrm{SW}$ & $\mathrm{E}_{3}: \mathrm{SS}$ & $\mathrm{E}_{3}: \mathrm{E}$ & \\
\hline
\end{tabular}


Finally, normalization weight vector is obtained via normalization as given in Table 6 . Then, the best contractor alternative with the proposed fuzzy VIKOR method becomes available. With respect with each criterion on Table 6, three experts evaluated the contractor alternatives. Evaluation results are given in Table 7. Fuzzy evaluation matrix is obtained as in Table 8 , by calculating the arithmetic means.

\section{Table 5}

Fuzzy evaluation matrix for the weights

\begin{tabular}{|c|c|c|c|c|c|c|c|c|c|}
\hline & $\mathrm{C}_{1}$ & $\mathrm{C}_{2}$ & $\mathrm{C}_{3}$ & $\mathrm{C}_{4}$ & $\mathrm{C}_{5}$ & $\mathrm{C}_{6}$ & $\mathrm{C}_{7}$ & $\mathrm{C}_{8}$ & $\mathrm{C}_{9}$ \\
\hline $\mathrm{C}_{\mathrm{l}}$ & 6 & $(0.89,1,1.33)$ & $(1.22,1.5,1.67)$ & $(1.06,1.33,1.5)$ & $(1,1,1.5)$ & $(0.89,1.33,1.67)$ & $(1.17,1.33,1.67)$ & $(1.17,1.33,1.5)$ & $(1,1.33,1.67)$ \\
\hline $\mathrm{C}_{2}$ & $(0.78,1,1.17)$ & $(1,1,1)$ & $(0.89,1.17,1.33)$ & $(0.83,1.06,1.5)$ & $(1,1.17,1.33)$ & $(1,1,1.33)$ & $(0.89,1.33,1.67)$ & $(0.89,1.17,1.5)$ & $(1,1,1.5)$ \\
\hline $\mathrm{C}_{3}$ & $(0.78,0.8,1)$ & $(0.83,0.89,1.17)$ & $(1,1,1)$ & $(0.89,1,1.33)$ & $(0.83,1.06,1.5)$ & $(0.89,1.17,1.33)$ & $(1,1.17,1.33)$ & $(1,1,1.17)$ & $(0.89,1.17,1.5)$ \\
\hline $\mathrm{C}_{4}$ & $(0.8,0.83,1.06)$ & $(0.72,1.06,1.33)$ & $(0.78,1,1.17)$ & $(1,1,1)$ & $(0.72,1.06,1.33)$ & $(0.94,1.33,1.5)$ & $(1,1,1.33)$ & $(1,1,1.17)$ & $(1.22,1.5,1.67)$ \\
\hline $\mathrm{C}_{5}$ & $(0.67,1,1)$ & $(0.83,0.89,1)$ & $(0.72,1.06,1.33)$ & $(0.83,1.06,1.5)$ & $(1,1,1)$ & $(0.83,0.89,1.33)$ & $(0.78,1.17,1.33)$ & $(0.78,1.17,1.33)$ & $(0.89,1,0.89)$ \\
\hline $\mathrm{C}_{6}$ & $(0.67,0.78,1.17)$ & $(0.78,1,1)$ & $(0.83,0.89,1.17)$ & $(0.8,0.83,1.22)$ & $(0.78,1.17,1.33)$ & $(1,1,1)$ & $(0.83,1.06,1.5)$ & $(0.83,0.89,1.33)$ & $(1,1,1.17)$ \\
\hline $\mathrm{C}_{7}$ & $(0.69,0.83,0.89)$ & $(0.67,0.78,1.17)$ & $(0.83,0.89,1)$ & $(0.78,1,1)$ & $(0.83,0.89,1.33)$ & $(0.72,1.06,1.33)$ & $(1,1,1)$ & $(0.89,1,1)$ & $(0.78,1.17,1.33)$ \\
\hline $\mathrm{C}_{8}$ & $(0.8,0.83,0.89)$ & $(0.72,0.89,1.17)$ & $(0.89,1,1)$ & $(0.89,1,1)$ & $(0.83,0.89,1.33)$ & $(0.78,1.17,1.33)$ & $(1,1,1.17)$ & $(1,1,1)$ & $(0.89,1.17,1.33)$ \\
\hline $\mathrm{C}_{9}$ & $(0.67,0.78,1)$ & $(0.67,1,1)$ & $(0.72,0.89,1.17)$ & $(0.78,0.8,1)$ & $(0.78,1,1.17)$ & $(0.89,1,1)$ & $(0.83,0.89,1.33)$ & $(0.83,0.89,1.17)$ & $(1,1,1)$ \\
\hline
\end{tabular}

Table 6

Results of the fuzzy AHP procedure for the determination of the weights

\begin{tabular}{llll}
\hline & $\tilde{s}_{j}=\widetilde{M}_{j}=\left(l_{j}, m_{j}, u_{j}\right)$ & $\dot{W}_{j}=\dot{d}\left(c_{j}\right)^{T}$ & $W_{j}=\mathrm{d}\left(c_{j}\right)^{T}$ \\
\hline $\mathrm{C}_{1}$ & $(0.094,0.134,0.191)$ & 1.000 & 0.152 \\
$\mathrm{C}_{2}$ & $(0.083,0.119,0.174)$ & 0.841 & 0.128 \\
$\mathrm{C}_{3}$ & $(0.081,0.111,0.16)$ & 0.743 & 0.113 \\
$\mathrm{C}_{4}$ & $(0.082,0.117,0.163)$ & 0.807 & 0.123 \\
$\mathrm{C}_{5}$ & $(0.074,0.111,0.152)$ & 0.713 & 0.109 \\
$\mathrm{C}_{6}$ & $(0.075,0.103,0.154)$ & 0.663 & 0.101 \\
$\mathrm{C}_{7}$ & $(0.072,0.103,0.142)$ & 0.613 & 0.093 \\
$\mathrm{C}_{8}$ & $(0.078,0.107,0.145)$ & 0.656 & 0.100 \\
$\mathrm{C}_{9}$ & $(0.072,0.099,0.139)$ & 0.564 & 0.086 \\
\hline
\end{tabular}

Therefore, using Eqs. (21)-(23), separation measure from the fuzzy best value $\tilde{\boldsymbol{S}}_{\boldsymbol{i}}$ and separation measure from the fuzzy worst value $\tilde{R}_{i}$ are computed as in Table 7. In the next step, using Eq. (24) $\tilde{S}^{*}, \tilde{S}^{-}, \widetilde{R}^{*}$ and $\widetilde{R}^{-}$fuzzy values are calculated (Table 8 ).

Then, using Eq. (25), $\tilde{Q}_{i}$ values are computed. In the calculations, weight of the strategy of the maximum group utility $(\boldsymbol{v})$ is assumed to be 0.5 . Finally $\tilde{Q}_{i}$ values are defuzzified via graded mean integration method (Eq. 26) and ranked according to Qi index values.

Table 7

Evaluation scores of the contractor alternatives

\begin{tabular}{|c|c|c|c|c|c|c|c|c|c|}
\hline & $\mathrm{C}_{1}$ & $\mathrm{C}_{2}$ & $\mathrm{C}_{3}$ & $\mathrm{C}_{4}$ & $\mathrm{C}_{5}$ & $\mathrm{C}_{6}$ & $\mathrm{C}_{7}$ & $\mathrm{C}_{8}$ & $\mathrm{C}_{9}$ \\
\hline \multirow[t]{3}{*}{$\mathrm{A}_{1}$} & $E_{1}: G$ & $\mathrm{E}_{1}: \mathrm{VG}$ & $\mathrm{E}_{1}: \mathrm{MG}$ & $\mathrm{E}_{1}: \mathrm{MP}$ & $\mathrm{E}_{1}: \mathrm{MG}$ & $\mathrm{E}_{1}: \mathrm{VG}$ & $\mathrm{E}_{1}: \mathrm{MG}$ & $\mathrm{E}_{1}: \mathrm{G}$ & $\mathrm{E}_{1}: \mathrm{MG}$ \\
\hline & $\mathrm{E}_{2}: \mathrm{G}$ & $E_{2}: F$ & $E_{2}: F$ & $E_{2}: F$ & $\mathrm{E}_{2}: \mathrm{MG}$ & $\mathrm{E}_{2}: \mathrm{MG}$ & $\mathrm{E}_{2}: \mathrm{MG}$ & $\mathrm{E}_{2}: \mathrm{MG}$ & $E_{2}: F$ \\
\hline & $\mathrm{E}_{3}: \mathrm{MG}$ & $E_{3}: F$ & $E_{3}: G$ & $\mathrm{E}_{3}: \mathrm{VG}$ & $\mathrm{E}_{3}: \mathrm{G}$ & $\mathrm{E}_{3}: \mathrm{MG}$ & $E_{3}: V G$ & $\mathrm{E}_{3}: \mathrm{G}$ & $E_{3}: F$ \\
\hline \multirow{3}{*}{$\mathrm{A}_{2}$} & $E_{1}: F$ & $\mathrm{E}_{1}: \mathrm{G}$ & $E_{1}: V G$ & $\mathrm{E}_{1}: \mathrm{P}$ & $E_{1}: G$ & $\mathrm{E}_{1}: \mathrm{MG}$ & $\mathrm{E}_{1}: \mathrm{P}$ & $E_{1}: V P$ & $E_{1}: F$ \\
\hline & $\mathrm{E}_{2}: \mathrm{G}$ & $E_{2}: F$ & $\mathrm{E}_{2}: \mathrm{VP}$ & $\mathrm{E}_{2}: \mathrm{VP}$ & $\mathrm{E}_{2}: \mathrm{G}$ & $\mathrm{E}_{2}: \mathrm{G}$ & $\mathrm{E}_{2}: \mathrm{P}$ & $\mathrm{E}_{2}: \mathrm{VP}$ & $E_{2}: F$ \\
\hline & $\mathrm{E}_{3}: \mathrm{G}$ & $E_{3}: G$ & $E_{3}: V G$ & $\mathrm{E}_{3}: \mathrm{G}$ & $\mathrm{E}_{3}: \mathrm{MP}$ & $\mathrm{E}_{3}: \mathrm{MG}$ & $E_{3}: V G$ & $E_{3}: V G$ & $E_{3}: F$ \\
\hline \multirow[t]{3}{*}{$\mathrm{A}_{3}$} & $\mathrm{E}_{1}: \mathrm{MP}$ & $\mathrm{E}_{1}: \mathrm{MP}$ & $E_{1}: F$ & $E_{1}: F$ & $\mathrm{E}_{1}: \mathrm{G}$ & $E_{1}: F$ & $E_{1}: F$ & $\mathrm{E}_{1}: \mathrm{F}$ & $E_{1}: G$ \\
\hline & $\mathrm{E}_{2}: \mathrm{F}$ & $E_{2}: F$ & $\mathrm{E}_{2}: \mathrm{MG}$ & $\mathrm{E}_{2}: \mathrm{MG}$ & $\mathrm{E}_{2}: \mathrm{MG}$ & $\mathrm{E}_{2}: \mathrm{F}$ & $\mathrm{E}_{2}: \mathrm{MG}$ & $\mathrm{E}_{2}: \mathrm{MG}$ & $\mathrm{E}_{2}: \mathrm{MG}$ \\
\hline & $\mathrm{E}_{3}: \mathrm{MP}$ & $E_{3}: F$ & $E_{3}: F$ & $E_{3}: G$ & $E_{3}: G$ & $\mathrm{E}_{3}: \mathrm{MG}$ & $E_{3}: G$ & $\mathrm{E}_{3}: \mathrm{MG}$ & $E_{3}: G$ \\
\hline \multirow[t]{3}{*}{$\mathrm{A}_{4}$} & $\mathrm{E}_{1}: \mathrm{F}$ & $\mathrm{E}_{1}: \mathrm{MP}$ & $\mathrm{E}_{1}: \mathrm{G}$ & $\mathrm{E}_{1}: \mathrm{MG}$ & $E_{1}: F$ & $\mathrm{E}_{1}: \mathrm{G}$ & $\mathrm{E}_{1}: \mathrm{F}$ & $\mathrm{E}_{1}: \mathrm{G}$ & $\mathrm{E}_{1}: \mathrm{MG}$ \\
\hline & $E_{2}: F$ & $E_{2}: F$ & $\mathrm{E}_{2}: \mathrm{MG}$ & $\mathrm{E}_{2}: \mathrm{G}$ & $E_{2}: F$ & $\mathrm{E}_{2}: \mathrm{MG}$ & $\mathrm{E}_{2}: \mathrm{MG}$ & $E_{2}: F$ & $E_{2}: G$ \\
\hline & $\mathrm{E}_{3}: \mathrm{MP}$ & $E_{3}: F$ & $\mathrm{E}_{3}: \mathrm{MP}$ & $E_{3}: G$ & $E_{3}: F$ & $\mathrm{E}_{3}: \mathrm{MG}$ & $\mathrm{E}_{3}: \mathrm{MG}$ & $\mathrm{E}_{3}: \mathrm{MG}$ & $\mathrm{E}_{3}: \mathrm{MG}$ \\
\hline \multirow[t]{3}{*}{$\mathrm{A}_{5}$} & $\mathrm{E}_{1}: \mathrm{G}$ & $E_{1}: F$ & $\mathrm{E}_{1}: \mathrm{G}$ & $\mathrm{E}_{1}: \mathrm{G}$ & $\mathrm{E}_{1}: \mathrm{G}$ & $\mathrm{E}_{1}: \mathrm{P}$ & $\mathrm{E}_{1}: \mathrm{G}$ & $\mathrm{E}_{1}: \mathrm{G}$ & $\mathrm{E}_{1}: \mathrm{G}$ \\
\hline & $\mathrm{E}_{2}: \mathrm{VG}$ & $\mathrm{E}_{2}: \mathrm{G}$ & $E_{2}: F$ & $\mathrm{E}_{2}: \mathrm{G}$ & $\mathrm{E}_{2}: \mathrm{VG}$ & $\mathrm{E}_{2}: \mathrm{MP}$ & $E_{2}: G$ & $E_{2}: G$ & $\mathrm{E}_{2}: \mathrm{MG}$ \\
\hline & $E_{3}: G$ & $E_{3}: G$ & $\mathrm{E}_{3}: \mathrm{MG}$ & $E_{3}: G$ & $E_{3}: V G$ & $\mathrm{E}_{3}: \mathrm{MG}$ & $E_{3}: G$ & $\mathrm{E}_{3}: \mathrm{MG}$ & $E_{3}: G$ \\
\hline
\end{tabular}


Table 8

Fuzzy evaluation matrix for the alternatives

\begin{tabular}{|c|c|c|c|c|c|c|c|c|c|}
\hline & $\mathrm{C}_{1}$ & $\mathrm{C}_{2}$ & $\mathrm{C}_{3}$ & $\mathrm{C}_{4}$ & $\mathrm{C}_{5}$ & $\mathrm{C}_{6}$ & $\mathrm{C}_{7}$ & $\mathrm{C}_{8}$ & $\mathrm{C}_{9}$ \\
\hline$\overline{A_{1}}$ & $(6.33,8.33,9.67)$ & $(5,6.67,8)$ & $(5,7,8.67)$ & $(4.33,6,7.33)$ & $(5.67,7.67,9.33)$ & $(6.33,8,9.33)$ & $(6.33,8,9.33)$ & $(6.33,8.33,9.67)$ & $(3.67,5.67,7.67)$ \\
\hline $\mathrm{A}_{2}$ & $(5.67,7.67,9)$ & $(5.67,7.67,9)$ & $(6,6.67,7)$ & $(2.33,3.33,4.67)$ & $(5,7,8.33)$ & $(5.67,7.67,9.33)$ & $(3,4,5.33)$ & $(3,3.33,4)$ & $(3,5,7)$ \\
\hline $\mathrm{A}_{3}$ & $(1.67,3.67,5.67)$ & $(2.33,4.33,6.33)$ & $(3.67,5.67,7.67)$ & $(5,7,8.67)$ & $(6.33,8.33,9.67)$ & $(3.67,5.67,7.67)$ & $(5,7,8.67)$ & $(4.33,6.33,8.33)$ & $(6.33,8.33,9.67)$ \\
\hline $\mathrm{A}_{4}$ & $(2.33,4.33,6.33)$ & $(2.33,4.33,6.33)$ & $(4.33,6.33,8)$ & $(6.33,8.33,9.67)$ & $(3,5,7)$ & $(5.67,7.67,9.33)$ & $(4.33,6.33,8.33)$ & $(5,7,8.67)$ & $(5.67,7.67,9.33)$ \\
\hline$A_{5}$ & $(7.67,9.33,10)$ & $(5.67,7.67,9)$ & $(5,7,8.67)$ & $(7,9,10)$ & $(8.33,9.67,10)$ & $(2,3.67,5.67)$ & $(7,9,10)$ & $(6.33,8.33,9.67)$ & $(6.33,8.33,9.67)$ \\
\hline
\end{tabular}

Table 9

Separation measures of $A_{i}$ from the fuzzy best and fuzzy worst values

\begin{tabular}{lcc}
\hline & $\tilde{S}_{i}$ & $\tilde{R}_{i}$ \\
\hline $\mathrm{A}_{1}$ & $(17.2,27.19,46.41)$ & $(2.9,6.66,11.57)$ \\
$\mathrm{A}_{2}$ & $(24.34,37.2,61.1)$ & $(4.78,7,14.14)$ \\
$\mathrm{A}_{3}$ & $(18.09,31.15,61.08)$ & $(2.98,8.23,12.6)$ \\
$\mathrm{A}_{4}$ & $(17.41,29.03,54.42)$ & $(2.86,7.36,11.35)$ \\
$\mathrm{A}_{5}$ & $(16.31,25.95,45.95)$ & $(2.64,6.66,12.67)$ \\
\hline
\end{tabular}

Table 10

$\tilde{S}^{*}, \tilde{S}^{-}, \tilde{R}^{*}$ and $\tilde{R}^{-}$values

\begin{tabular}{cl}
$\tilde{S}^{*}$ & $(16.31,25.95,45.95)$ \\
$\tilde{S}^{-}$ & $(24.34,37.2,61.1)$ \\
$\tilde{R}^{*}$ & $(2.64,6.66,11.35)$ \\
$\tilde{R}^{-}$ & $(4.78,8.23,14.14)$ \\
\hline
\end{tabular}

Table 11

Integrated fuzzy VIKOR-AHP analysis results

\begin{tabular}{lccc}
\hline & $\tilde{Q}_{i}$ & $\mathrm{Q}_{\mathrm{i}}$ & Rank order \\
\hline $\mathrm{A}_{1}$ & $(-2.46,0.05,3.96)$ & 0.29 & 2 \\
$\mathrm{~A}_{2}$ & $(-1.89,0.61,5.48)$ & 1.00 & 5 \\
$\mathrm{~A}_{3}$ & $(-2.42,0.73,5.11)$ & 0.94 & 4 \\
$\mathrm{~A}_{4}$ & $(-2.47,0.36,4.41)$ & 0.56 & 3 \\
$\mathrm{~A}_{5}$ & $(-2.54,0,4.19)$ & 0.27 & 1 \\
\hline
\end{tabular}

Results of the integrated fuzzy VIKOR-AHP analysis results are in Table 11. The ranking of the alternatives in descending order are $\mathrm{A}_{5}, \mathrm{~A}_{1}, \mathrm{~A}_{4}, \mathrm{~A}_{3}$, and $\mathrm{A}_{2}$, that is based on the crisp $\mathrm{Q}_{\mathrm{i}}$ index values. The best alternative is found to be $A_{5}$. The second best alternative is $A_{1}$.

\section{Concluding remarks}

In this paper, an integrated fuzzy VIKOR-AHP methodology is developed for the selection of the best contractor in one of Iran construction industry projects. VIKOR is a multi-criteria decision making technique which provides a compromise solution, providing a maximum group utility for the majority and a minimum of an individual regret for the opponent. In fuzzy VIKOR, linguistic evaluations of the experts can easily be converted to fuzzy numbers which are allowed to be used in calculations. In this study, weights of the selection criteria are determined based on a fuzzy AHP approach in order to allow both pairwise comparisons and the utilization of linguistic variables. Despite the demanding nature of the pairwise comparisons approach, as it is considered to offer maximum insight and consistency, we choose modifying the existing fuzzy VIKOR methodology with the weights of the extent analysis.

\section{References}

Alarcón, L.F. \& Mourgues, C. (2002). Performance modeling for contractor selection. Journal of Management in Engineering, 18 (2), 52-60 ASCE. 
Banaitienê, N., \& Banaitis, A. (2006). Analysis of criteria for contractors' qualification evaluation. Technological and Economic Development of Economy, 12 (4), 276-282.

Bayazit, O. (2006). Use of analytic network process in vendor selection decisions. Benchmarking: An International Journal, 13(5), 566-579.

Chan, A.P.C., \& Chan, A.P.L. (2004). Key performance indicators for measuring construction success. Benchmarking: An International Journal, 11(2), 203-221.

Chang, D. Y. (1996). Applications of the extent analysis method on fuzzy AHP. European Journal of Operational Research, 95, 649-655.

Chen, C. (2000). Extensions of the TOPSIS for group decision-making under fuzzy environment. Fuzzy Sets and Systems, 114, 1-9.

Cheng, E.W.L., \& Li, H. (2004). Contractor selection using the analytic network process. Construction Management and Economics, 22, 1021-1032.

Crowley, L.G., \& Hancher, D.E. (1995). Evaluation of competitive bids. Journal of Construction Engineering and Management, 121 (2), 238-245 ASCE.

Demirtas, E.A., \& Stun O, U. (2008). An integrated multi-objective decision making process for supplier selection and order allocation. Omega, (36), 76-90.

Duckstein, L., \& Opricovic, S. (1980). Multiobjective optimization in river basin development. Water Resources Research, 16(1), 14-20.

Hatush, Z., \& Skitmore, M. (1998). Contractor selection using multi-criteria utility theory: an additive model. Building and Environment, 33(2-3), 105-115.

Holt, G.D., Olomolaiye, P.O., \& Harris, F.C. (1993). A conceptual alternative to current tendering practice. Building Research and Information, 21(3), 167-172.

Holt, G.D., Olomolaiye, PO., \& Harris, F.C. (1995). A review of contractor selection practice in the UK construction industry. Building and Environment, 30(4), 553-561.

Holt, G.D. (1998). Which contractor selection methodology? International Journal of Project Management, 1998, 16(3), 153-164.

Huang, S.H., \& Keskar, H. (2007). Comprehensive and configurable metrics for supplier selection. International Journal of Production Economics, 105, 510-123.

Hwang, C.H., \& Yoon, K. (1981). Lecture notes in economics and mathematical systems. Berlin: Springer-Verlag.

Jaselskis, E.J., \& Russell, J.S. (1992). Risk analysis approach to selection of contractor evaluationmethod. Journal of Construction Engineering and Management, 118 (4), 814-821.

Jaskowski, P. (2008). Designing the structure of a construction project operating system using evolutionary algorithm. Archives of Civil Engineering LIV 2, 371-394.

Jaskowski, P., \& Sobotka, A. (2006). Multicriteria construction project scheduling method using evolutionary algorithm. Operational Research. An International Journal, 6 (3), 283-297.

Juan, Y.-K. Perng, Y.-H. Castro-Lacouture, D., \& Lu, K.-S. (2009). Housing refurbishment contractors selection based on a hybrid fuzzy-QFD approach. Automation in Construction, 18139-144.

Kadefors, A., Bjö rlingson, E., \& Karlsson, A. (2007). Procuring service innovations: contractor selection for partnering projects. International Journal of Project Management, 25, 375-85.

Kashiwhgi, D., \& Byfield, R.E. (2002). Selecting the best contractor to get performance: on time, on budget, meeting quality expectations. Journal of Facilities Management, 1(2), 103-116.

Kaufmann, A., \& Gupta, M. M. (1985). Introduction to fuzzy arithmetic: Theory and applications. New York: Van Nostrand Reinhold.

Kumaraswamy, M.M. (1996). Contractor evaluation and selection - Hong Kong perspective. Building and Environment, 31(3), 273-282.

Lam, K.C., Hu, T.S., \& Ng, S.T. (2005). Using the principal component analysis method as a tool in contractor pre-qualification. Construction Management and Economics, 23 (7), 673-684.

Lam, K.Ch., Palaneeswaran, E., \& Yu, Ch.-Y. (2009). A support vector machine model for contractor prequalification. Automation in Construction, 18, 321-329.

Luu, D.T., Ng, ST., \& Chen, S.E. (2003). Parameters governing the selection of procurement system - an empirical survey. Engineering. Construction and Architectural Management, 10(3), 209-218.

McCabe, B., Tran, V., \& Ramani, J. (2005). Construction prequalification using data envelopment analysis. Canadian Journal of Civil Engineering, 32, 183-193. 
Minchin, R.E., \& Smith, G.R. (2005). Quality-based contractor rating model for qualification and bidding purposes. Journal of Management in Engineering, 21 (1), 38-43 ASCE.

Mohantry, R.P., Agarwal, R., Choudhury, A.K., \& Tiwari, M.K. (2005). A fuzzy ANP-based approach to R\&D project selection: a case study. International Journal of Production, 43(24), 5199-216.

Molenaar, K.R., \& Johnson, D.E. (2003). Engineering the procurement phase to achieve the best value. Leadership and Management, 3 (3), 137-141.

Opricovic, S., \& Tzeng, G.H. (2004). The compromise solution by MCDM methods: A comparative analysis of VIKOR and TOPSIS. European Journal of Operational Research, 156(2), 445-455.

Opricovic, S. (1998). Multicriteria optimization of civil engineering systems (in Serbian, Visekriterijumska optimizacija sistema u gradjevinarstvu). Belgrade: Faculty of Civil Engineering.

Opricovic, S. (2007). A fuzzy compromise solution for multicriteria problems. International Journal of Uncertainty, Fuzziness and Knowledge-based Systems, 15(3), 363-380.

Palaneeswaran, E., \& Kumaraswamy, M. (2001). Recent advances and proposed improvements in contractor prequali3cation methodologies. Building and Environment, 36, 73-87.

Ravi, V., Shankar, R., \& Tiwari, M.K. (2005). Analyzing alternatives in reverse logistics for end-of-life computers: ANP and balanced scorecard approach. Computers and Industrial Engineering, 48, 327356.

Russell, J.S., \& Skibniewski, M.J. (1990). Qualifier-2: knowledge-based system for contractor prequalification. Journal of Construction Engineering and Management, 116 (1), 157-171 ASCE.

Russell, J.S., Hancher, D.E., \& Skibniewski, M.J. (1992). Contractor prequalification data for construction owner. Construction Management and Economics, 10 (2), 117-135.

Singh, D., \& Tiong, R. (2006). Contractor selection criteria: investigation of opinions of Singapore construction practitioners. Journal of Construction Engineering and Management, 132 (9), 998-1008 ASCE.

Sultan, A., \& Tarawneh, (2004). Evaluation of Pre-qualification Criteria: Client Perspective; Jordan Case Study. Journal of Applied Sciences, 4, 354-363.

Ng, S.T., \& Skitmore, M. (1999). Client and consultant perspectives of prequalification criteria. Building and Environment, 34, 607-21.

Topcu, Y.I. (2004). A decision model proposal for construction contractor selection in Turkey. Building and Environment, 39, 469-81.

Turkis, Z. (2008). Multi-attribute contractors ranking method by applying ordering of feasible alternatives of solutions in terms of preferability technique. Technological and Economic Development of Economy, 14 (2), 224-239.

Wang, T.-C., Liang, L.-J., \& Ho, C.-Y. (2006). Multi-criteria decision analysis by using fuzzy VIKOR. In Proceedings of international conference on service systems and service management, 2, 901-906.

Wong, C.H., Holt, G.D., \& Cooper, P.A. (2000). Lowest price or value? Investigation of UK construction clients' tender selection process. Construction Management and Economics, 18 (7), $767-$ 774.

Wong, C.H., Holt, G.D., \& Nicholas, J. (2003). Using multivariate techniques for developing contractor classification models. Engineering, Construction and Architectural Management, 10 (2), 99-116.

Yasamis, F., Arditi, D., \& Mohammadi, J. (2002). Assessing contractor quality performance. Construction Management and Economics. 20, 211-223.

Yong, D. (2006). Plant location selection based on fuzzy TOPSIS. International Journal of Advanced Manufacturing Technologies, 28, 839-844.

Yu, P. L. (1973). A class of solutions for group decision problems. Management Science, 19(8), 936-946.

Zadeh, L. A. (1975). The concept of a linguistic variable and its application to approximate reasoning. Information Sciences, 8. 199-249 (I), 301-357 (II).

Zavadaskas, E.K., \& Vilutiene, T. A. (2006). Multiple criteria evaluation of multi-family apartment block's maintenance contractors: I- model for maintenance contractor evaluation and the determination of its selection criteria. Building and Environment, 41, 621-32.

Zeleny, M. (1982). Multiple Criteria Decision Making. New York: McGraw-Hill.

Zimmermann, H. J. (1991). Fuzzy Set Theory and its Applications (2 ${ }^{\text {nd }}$ ed.). Boston/ Dordrech/London: Kluwer Academic Publishers. 